\title{
SCIDiC
}

International Journal of Dentistry and Oral Science (IJDOS)

ISSN: 2377-8075

\section{Assessment Of Knowledge, Attitude and Practice On Treatment Planning For Esthetic Cases Between Specialists and General Practitioners}

Research Article

Subash Sharma ${ }^{1 *}$, Sneha Pai ${ }^{2}$

${ }^{1}$ Professor, Department of Conservative Dentistry \& Endodontics, Saveetha Dental College and Hospitals, Saveetha Institute of Medical and Technical Sciences, Saveetha University, Chennai, India.

${ }^{2}$ Department of Conservative Dentistry \& Endodontics, Saveetha Dental College and Hospitals, Saveetha Institute of Medical and Technical Sciences, Saveetha University, Chennai, India.

\section{Abstract}

With the development of technology, esthetic dentistry these days has reached new heights. This has led more patients to seek dental treatment to improve esthetics. There are several aspects to be considered while planning esthetic dental treatment which requires a thorough clinical examination and diagnosis. The factors that govern the outcome of esthetic dental treatment comprise both extra oral and intraoral features. These factors aid in the treatment planning which in turn helps predicting the outcome and success of esthetic restorative treatment. This survey aims to assess the knowledge, attitude and practice on treatment planning in esthetic dentistry by specialists and dental practitioners. This survey was carried out by designing a questionnaire containing 15 questions on Google forms which was circulated among dentists. The questions were based on knowledge, attitude and practice on esthetic treatment planning in dentistry. The responses were viewed in M.S. office excel and the results were interpreted using graphs by SPSS 23.0 version. Of the 120 dentists among whom the questionnaire was circulated, 87 responded, showing a response rate of $63.8 \%$. Analysis showed that the dentists showed some lack of theoretical knowledge due to which application of concepts to clinical scenarios was moderate. This survey indicated the need for educational intervention to improve the knowledge, attitude and practice on treatment planning for esthetic cases.

Keywords: Esthetic Dentistry; Treatment Planning; Bleaching; Laminates; Veneers; Ceramics.

\section{Introduction}

With modernization of technology, esthetic restorative dentistry has reached new horizons which has made patients seek treatment not only for restoration of teeth for form and function but also to attain esthetic appearance [1]. To reach this desired target, dental professionals have to understand the patient's perception of esthetics and the results they desire to achieve in order to plan the treatment [2]. The aspects of esthetic examination that need to be considered for treatment planning include midline position, lip fullness, incisal edge position, occlusion, the desired color change and the shapes of the teeth [3].
The first and the most important consideration is the patient's expectations. It is important for the dentist to understand the patient's esthetic concern prior to treatment planning. Since the esthetic judgement is subjective, dentists should not impose their opinions on the patient [4-6]. After understanding the patient's desires, the dentist should confirm them with a preview technique that includes a direct composite mock up, a wax up or computer imaging [7-9].

Midline discrepancy that is often identified during clinical examination and is believed to commonly occur in $30 \%$ of the indi-

*Corresponding Author:

Subash Sharma,

Professor, Department of Conservative Dentistry \& Endodontics, Saveetha Dental College and Hospitals, Saveetha Institute of Medical and Technical Sciences, Saveetha University 162, Poonamallee High Road, Chennai 600077, Tamilnadu, India.

Tel: +919884533118

Email Id: subash@saveetha.com

Received: May 05, 2021

Accepted: May 28, 2021

Published: May 30, 2021

Citation: Subash Sharma, Sneha Pai. Assessment Of Knowledge, Attitude and Practice On Treatment Planning For Esthetic Cases Between Specialists and General Practitioners. Int J Dentistry Oral Sci. 2021;08(05):2581-2585. doi: http://dx.doi.org/10.19070/2377-8075-21000505

Copyright: Subash Sharma ${ }^{\circ} 2021$. This is an open-access article distributed under the terms of the Creative Commons Attribution License, which permits unrestricted use, distribution and reproduction in any medium, provided the original author and source are credited. 
viduals [10-12]. For dental esthetic treatment, attempts have to be made to coincide facial and dental midlines as much as possible in order to achieve an ideal smile $[13,14]$. Also lip fullness has to be evaluated as lips guide facio-lingual positioning of the teeth [15-17]. The treatment planning involves classifying lips as thin, medium and thick [18]. This classification would guide the thickness of the restorations for esthetic treatment.

Incisal edge position becomes the most important determinant in smile designing $[18,19]$. It dictates the position of the teeth and helps establish the levels of gingiva. Since incisal edge position defines the age of an individual to some extent, its position can be altered to suit the age and achieve desired esthetic outcomes [20, 21]. While carrying out all these alterations, care has to be taken such that the principles of occlusion like anterior guidance and pathways of motion are not violated [22-24].

When the patient desires to have their tooth shape altered, sex and age of the individual has to be looked in to. In order to achieve an esthetic smile, it is important to have symmetry of maxillary incisors [25-27]. When alteration of tooth shape is planned for esthetic correction, symmetry in tooth form and contours of the lateral incisors and canines have also to be established along with buccal corridor gradation $[28,29]$. The last and the most common factor for which patients often visit the dental clinic is change in tooth color. There are several treatment options for correction of discolored teeth which ranges from bleaching (vital and non vital) to direct or indirect anterior restorations. The choice of treatment for such cases depends on the status of the teeth being treated [30]. Therefore a thorough clinical examination along with assessment of a patient's desires of an esthetic smile have to be studied for planning the treatment.

Previously our team has a rich experience in working on various research projects across multiple disciplines [31-45] Now the growing trend in this area motivated us to pursue this project.
The aim of this study was to assess the knowledge attitude and practice on treatment planning for esthetic cases between specialists and general practitioners.

\section{Materials and Methods}

This cross sectional survey was carried out in the month of April 2020. The participants included both specialists and general practitioners. A questionnaire was designed consisting of 15 questions. The first 5 questions evaluated the knowledge of the dentist regarding treatment planning for esthetic cases while the next 5 questions were designed to assess their attitude towards planning an esthetic treatment. The last 5 questions assessed the application of knowledge and attitude of the dentists in clinical scenarios.

The questions were put up on Google forms which were circulated among 105 dentists of which only 67 responded. The collected data was entered and viewed in MS office excel sheet following which graphical representation and interpretation of results was obtained. Participation of dentists in this survey was voluntary and their data was kept confidential.

\section{Results and Discussion}

The survey showed a response rate of $63.8 \%$. Of the 67 responses obtained, $61.2 \%$ were from specialists and $38.8 \%$ were from general practitioners. The responses to knowledge (Figures 1-4), attitude (Figures 5,6) and practice based questions were plotted in the graph and interpreted.

Esthetic examination is of prime importance while treatment planning of esthetic cases. This involves patients' expectations, midline position, lip fullness, incisal edge position, occlusion, the shapes of the teeth and the desired color change. The dentist

Figure 1. This bar graph represents the responses obtained from dentists regarding the location of facial midline during esthetic treatment planning. There is a statistically significant difference in the response between general dentists and specialists (Chi square value- 7.986; df-3; p value-0.046).

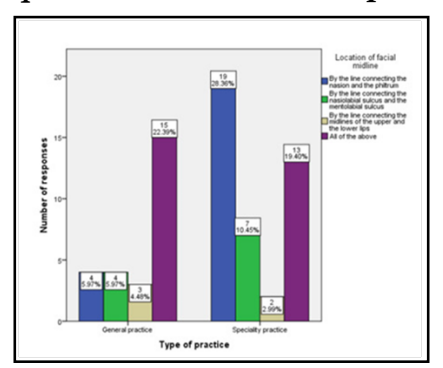

Figure 2. Bar graph shows the various responses for phonetic or speech evaluation chosen by dentists. There is a statistically significant difference in the responses opted by the two groups (Chi square value-9.122; df-2; $\mathrm{p}$ value-0.010).

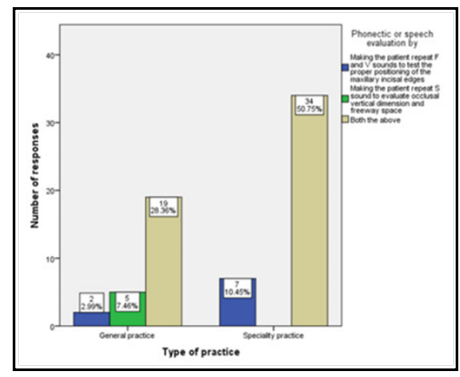


Figure 3. Bar graph denotes the various responses opted by specialists and general practitioners regarding their views on an ideal maxillary and mandibular relationship. There is a statistically significant difference in the responses between the two groups (Chi square value-15.119; df- 2 ; p value-0.001).

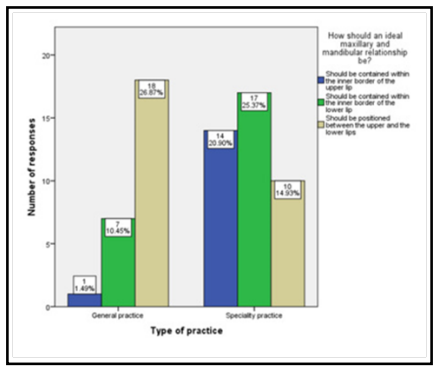

Figure 4. This graph indicates the various responses of the dentists regarding the reason for color discrepancy of veneers. There is a statistically significant difference in the responses between general dentists and specialists (Chi square value8.521; df-3; p value- 0.036). This graph infers that failure to bleach the discoloured tooth prior to the placement of veneers, dimensions of veneers as well as tooth preparation are the major reasons for color discrepancy of veneers.

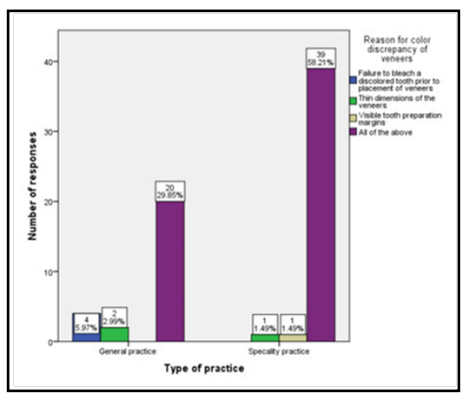

Figure 5. Graph representing the responses of dentists regarding the thickness of the veneers in relation to lip forms. This graph shows no statistically significant in the responses between the groups (Chi square value- $0.981 ; \mathrm{df}-2$; $\mathrm{p}$ value- 0.612 ). Graph also infers that the medium lip form will be more accepted followed by thin lip forms.

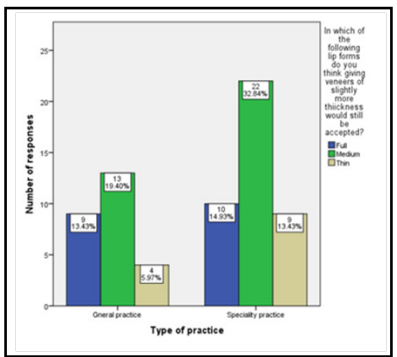

Figure 6. Graph depicting the responses for one of the major drawbacks of no prep veneers. There is a statistically significant difference in the responses between the two groups (Chi square value- 9.850; df- 2; p value- 0.007). Graph reveals that the major drawback of no preparation veneers would be a compromised durability of the veneers.

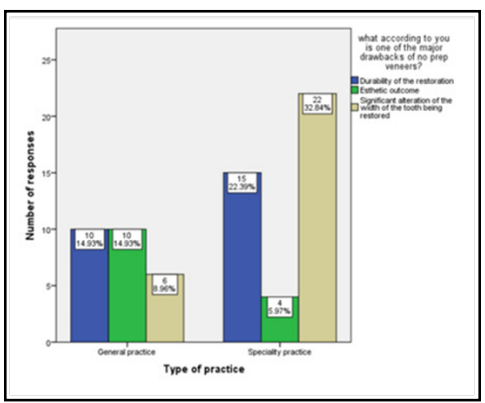

must always prioritize the patient's desires and inform them of all the options available prior to treatment planning [46]. Some patients may decline the interdisciplinary approach in treatment planning there by placing limitations on the esthetic results while some would readily agree for multidisciplinary intervention to achieve better esthetic outcomes [3]. No matter what the patient's preferences are, their consent and requirements must be consid- ered and a mock up should be done either digitally or manually before finalizing the treatment plan [7].

Midline discrepancies that are often noticed during clinical examination usually go unnoticed by lay people unless the midline has been offcentered by more than 4mm [4]. Although midline discrepancies can be corrected with restorations, severe discrep- 
ancies cannot be altered as the gingival tissue would not adjust to severe changes resulting in compromised interproximal tissue health $[47,48]$.

Another important factor to be considered is the lip fullness. Lips are believed to guide the facio lingual positioning of the teeth [15]. The maxillary incisal profile is set so that it is contained within the inner border of the lower lip which in turn provides adequate closure of the lips $[13,49]$. Before altering anterior esthetics, the lips have to be classified as thin, medium and full [59]. Presence of thin lips would alter the lip support and facial esthetics with increase in thickness of the restorative material [3]. Also, while working on anterior esthetics, the length of the anterior teeth have to be evaluated. The patient is asked to pronounce words with "M", "F" and "V" sounds such that the position of the teeth at rest and the appropriate length of the teeth is established [50, 51].

While working on anterior esthetic cases, care has to be taken such that the principles of occlusion are not violated. In cases where patients desire a change in tooth shape, size and contour, the treatment has to be planned such that the restoration would blend in well with the age and gender of the patient. When working with no prep veneers, it has to be noted that it cannot be used for altering the widths of the teeth being restored [52].

In cases requiring change in the shade of the tooth, various options can be exercised based on the status of the tooth. The most conservative technique for color change of teeth being bleaching, non vital or vital bleaching can be practiced based on the vitality of the tooth. When the tooth shows no response to bleaching, laminates and veneers can be used to mask the underlying discolored tooth and finally a full veneer crown can be planned in teeth with deficient tooth structure or where bleaching, laminates and veneers fail to conceal the discolored tooth. No preparation or minimal preparation veneers are commonly in practice these days are being used for cases that require minimal esthetic correction.

The treatment plan for esthetic cases relies on several factors and has to be well judged during clinical examination to obtain satisfactory results. Our institution is passionate about high quality evidence based research and has excelled in various fields [53-63].

\section{Conclusion}

There are various treatment modalities to achieve esthetic outcomes. To achieve a satisfactory outcome, a well designed treatment plan is required that varies with every case and has to be designed based on several extraoral and intraoral factors. This survey showed lack of knowledge among dentists regarding the factors that govern esthetic treatment planning and failure of application of knowledge to clinical scenarios. Further educational intervention is required to improve knowledge, attitude and practice of general dentists in treatment planning of esthetic cases.

\section{Acknowledgements and Declaration}

All the authors have equally contributed to this study. There are no conflicts of interest.

\section{References}

[1]. Hussain AS, Masood TM. Esthetic restorative treatment planning for dental professionals: an overview. EC Dent Sci. 2017;15(1):191-5.

[2]. Tin-Oo MM, Saddki N, Hassan N. Factors influencing patient satisfaction with dental appearance and treatments they desire to improve aesthetics. BMC Oral Health. 2011 Feb 23;11:6. Pubmed PMID: 21342536.

[3]. Javaheri D. Considerations for planning esthetic treatment with veneers involving no or minimal preparation. J Am Dent Assoc. 2007 Mar;138(3):3317. Pubmed PMID: 17332038.

[4]. Kokich VO Jr, Kiyak HA, Shapiro PA. Comparing the perception of dentists and lay people to altered dental esthetics. J Esthet Dent. 1999;11(6):311-24. Pubmed PMID: 10825866.

[5]. Vallittu PK, Vallittu AS, Lassila VP. Dental aesthetics--a survey of attitudes in different groups of patients. J Dent. 1996 Sep;24(5):335-8. Pubmed PMID: 8916647.

[6]. Wagner IV, Carlsson GE, Ekstrand K, Odman P, Schneider N. A comparative study of assessment of dental appearance by dentists, dental technicians, and laymen using computer-aided image manipulation. J Esthet Dent. 1996;8(5):199-205. Pubmed PMID: 9468841.

[7]. Magne P, Magne M, Belser U. The diagnostic template: a key element to the comprehensive esthetic treatment concept. Int J Periodontics Restorative Dent. 1996 Dec;16(6):560-9. Pubmed PMID: 9242094.

[8]. Morley J. The role of cosmetic dentistry in restoring a youthful appearance. J Am Dent Assoc. 1999 Aug;130(8):1166-72. Pubmed PMID: 10491926.

[9]. Magne P, Belser UC. Novel porcelain laminate preparation approach driven by a diagnostic mock-up. J Esthet Restor Dent. 2004;16(1):7-16; discussion 17-8. Pubmed PMID: 15259539.

[10]. Kokich V. Esthetics and anterior tooth position: an orthodontic perspective. Part III: Mediolateral relationships. J Esthet Dent. 1993;5(5):200-7. Pubmed PMID: 8037970.

[11]. Miller EL, Bodden WR Jr, Jamison HC. A study of the relationship of the dental midline to the facial median line. J Prosthet Dent. 1979 Jun;41(6):657-60. Pubmed PMID: 374721.

[12]. Morley J, Eubank J. Macroesthetic elements of smile design. J Am Dent Assoc. 2001 Jan;132(1):39-45. Pubmed PMID: 11194397.

[13]. POUND E. Esthetic dentures and their phonetic values. J Prosthet Dent. 1951 Jan-Mar;1(1-2):98-111. Pubmed PMID: 14814654.

[14]. Frush JP, Fisher RD. Introduction to dentogenic restorations. The Journal of Prosthetic Dentistry. 1955 Sep 1;5(5):586-95.

[15]. Dong JK, Jin TH, Cho HW, Oh SC. The esthetics of the smile: a review of some recent studies. Int J Prosthodont. 1999 Jan-Feb;12(1):9-19. Pubmed PMID: 10196823.

[16]. Tweed $\mathrm{CH}$. The diagnostic facial triangle in the control of treatment objectives. Am J Orthod. 1969 Jun;55(6):651-7. Pubmed PMID: 5253959.

[17]. Matthews TG. The anatomy of a smile. J Prosthet Dent. 1978 Feb;39(2):12834. Pubmed PMID: 271728.

[18]. Oliver BM. The influence of lip thickness and strain on upper lip response to incisor retraction. Am J Orthod. 1982 Aug;82(2):141-9. Pubmed PMID: 6961784.

[19]. Gürel G, Gürel G. The science and art of porcelain laminate veneers. Berlin: Quintessence; 2003 Jan.

[20]. Wolfart S, Thormann H, Freitag S, Kern M. Assessment of dental appearance following changes in incisor proportions. Eur J Oral Sci. 2005 Apr;113(2):159-65. Pubmed PMID: 15819823.

[21]. Vig RG, Brundo GC. The kinetics of anterior tooth display. J Prosthet Dent. 1978 May;39(5):502-4. Pubmed PMID: 349139.

[22]. Shillingburg HT, Hobo S, VVhitsett LD. Fundamentals of fixed prosthodontics, ûuintessence Publish Co.

[23]. Hunt KH. Full-mouth multidisciplinary restoration using the biological approach: a case report. Pract Proced Aesthet Dent. 2001 JunJul;13(5):399-406; quiz 407. Pubmed PMID: 11504460.

[24]. McIntyre FM, Jureyda O. Occlusal function. Beyond centric relation. Dent Clin North Am. 2001 Jan;45(1):173-80. Pubmed PMID: 11210694.

[25]. Javaheri DS, Shahnavaz S. Utilizing the concept of the golden proportion. Dent Today. 2002 Jun;21(6):96-101. Pubmed PMID: 12073486.

[26]. Garn SM, Lewis AB, Kerewsky RS. Sex difference in tooth shape. J Dent Res. 1967 Nov-Dec;46(6):1470. Pubmed PMID: 5234920.

[27]. Lavelle CL. Maxillary and mandibular tooth size in different racial groups and in different occlusal categories. Am J Orthod. 1972 Jan;61(1):29-37. Pubmed PMID: 4500185.

[28]. Ward DH. Proportional Smile Design: Using the Recurring Esthetic Dental Proportion to Correlate the Widths and Lengths of the Maxillary Anterior Teeth with the Size of the Face. Dent Clin North Am. 2015 Jul;59(3):62338. Pubmed PMID: 26140969.

[29]. Preston JD. The golden proportion revisited. J Esthet Dent. 1993;5(6):247- 
51. Pubmed PMID: 7993669.

[30]. Roberson T, Heymann HO, Swift Jr EJ. Sturdevant's art and science of operative dentistry. Elsevier Health Sciences; 2006 Apr 13.

[31]. Govindaraju L, Gurunathan D. Effectiveness of Chewable Tooth Brush in Children-A Prospective Clinical Study. J Clin Diagn Res. 2017 Mar;11(3):ZC31-ZC34. Pubmed PMID: 28511505.

[32]. Christabel A, Anantanarayanan P, Subash P, Soh CL, Ramanathan M, Muthusekhar MR, et al. Comparison of pterygomaxillary dysjunction with tuberosity separation in isolated Le Fort I osteotomies: a prospective, multi-centre, triple-blind, randomized controlled trial. Int J Oral Maxillofac Surg. 2016 Feb;45(2):180-5. Pubmed PMID: 26338075.

[33]. Soh CL, Narayanan V. Quality of life assessment in patients with dentofacial deformity undergoing orthognathic surgery--a systematic review. Int J Oral Maxillofac Surg. 2013 Aug;42(8):974-80. Pubmed PMID: 23702370.

[34]. Mehta M, Deeksha, Tewari D, Gupta G, Awasthi R, Singh H, et al. Oligonucleotide therapy: An emerging focus area for drug delivery in chronic inflammatory respiratory diseases. Chem Biol Interact. 2019 Aug 1;308:206215. Pubmed PMID: 31136735.

[35]. Ezhilarasan D, Apoorva VS, Ashok Vardhan N. Syzygium cumini extract induced reactive oxygen species-mediated apoptosis in human oral squamous carcinoma cells. J Oral Pathol Med. 2019 Feb;48(2):115-121. Pubmed PMID: 30451321

[36]. Campeau PM, Kasperaviciute D, Lu JT, Burrage LC, Kim C, Hori M, et al. The genetic basis of DOORS syndrome: an exome-sequencing study. Lancet Neurol. 2014 Jan;13(1):44-58. Pubmed PMID: 24291220.

[37]. Sneha S. Knowledge and awareness regarding antibiotic prophylaxis for infective endocarditis among undergraduate dental students. Asian Journal of Pharmaceutical and Clinical Research. 2016 Oct 1:154-9.

[38]. Christabel SL, Gurunathan D. Prevalence of type of frenal attachment and morphology of frenum in children, Chennai, Tamil Nadu. World J Dent. 2015 Oct;6(4):203-7.

[39]. Kumar S, Rahman RE. Knowledge, awareness, and practices regarding biomedical waste management among undergraduate dental students. Asian Journal of Pharmaceutical and Clinical Research. 2017;10(8):341.

[40]. Sridharan G, Ramani P, Patankar S. Serum metabolomics in oral leukoplakia and oral squamous cell carcinoma. J Cancer Res Ther. 2017 JulSep;13(3):556-561. Pubmed PMID: 28862226.

[41]. Ramesh A, Varghese SS, Doraiswamy JN, Malaiappan S. Herbs as an antioxidant arsenal for periodontal diseases. J Intercult Ethnopharmacol. 2016 Jan 27;5(1):92-6. Pubmed PMID: 27069730.

[42]. Thamaraiselvan M, Elavarasu S, Thangakumaran S, Gadagi JS, Arthie T. Comparative clinical evaluation of coronally advanced flap with or without platelet rich fibrin membrane in the treatment of isolated gingival recession. J Indian Soc Periodontol. 2015 Jan-Feb;19(1):66-71. Pubmed PMID: 25810596.

[43]. Thangaraj SV, Shyamsundar V, Krishnamurthy A, Ramani P, Ganesan K, Muthuswami M, et al. Molecular Portrait of Oral Tongue Squamous Cell Carcinoma Shown by Integrative Meta-Analysis of Expression Profiles with Validations. PLoS One. 2016 Jun 9;11(6):e0156582. Pubmed PMID: 27280700 .

[44]. Ponnulakshmi R, Shyamaladevi B, Vijayalakshmi P, Selvaraj J. In silico and in vivo analysis to identify the antidiabetic activity of beta sitosterol in adipose tissue of high fat diet and sucrose induced type- 2 diabetic experimental rats. Toxicol Mech Methods. 2019 May;29(4):276-290. Pubmed PMID: 30461321

[45]. Ramakrishnan M, Bhurki M. Fluoride, Fluoridated Toothpaste Efficacy And Its Safety In Children-Review. International Journal of Pharmaceutical Research. 2018 Oct 1;10(04):109-14.

[46]. Levin RP. The new patient experience: Part 3--Ten steps to a successful new patient initial visit. Pract Proced Aesthet Dent. 2003 Aug;15(7):543-4. Pubmed PMID: 14509096.
[47]. Kois JC. The restorative-periodontal interface: biological parameters. Periodontol 2000. 1996 Jun;11:29-38. Pubmed PMID: 9567954.

[48]. KOHL JT, ZANDER HA. Morphology of interdental gingival tissues. Oral Surg Oral Med Oral Pathol. 1961 Mar;14:287-95. Pubmed PMID: 13757572.

[49]. Burstone CJ. Lip posture and its significance in treatment planning. Am J Orthod. 1967 Apr;53(4):262-84. Pubmed PMID: 5227460.

[50]. Small BW. Location of incisal edge position for esthetic restorative dentistry. Gen Dent. 2000 Jul-Aug;48(4):396-7. Pubmed PMID: 11199612.

[51]. Chiche G, Pinault A. Artistic and scientific principles applied to esthetic dentistry. Esthetics of anterior fixed prosthodontics. Chicago: Quintessence Books. 1994:13-32.

[52]. Gürel G. Predictable, precise, and repeatable tooth preparation for porcelain laminate veneers. Pract Proced Aesthet Dent. 2003 Jan-Feb;15(1):17-24, quiz 26. Pubmed PMID: 12680057.

[53]. Vijayashree Priyadharsini J. In silico validation of the non-antibiotic drugs acetaminophen and ibuprofen as antibacterial agents against red complex pathogens. J Periodontol. 2019 Dec;90(12):1441-1448. Pubmed PMID: 31257588.

[54]. J PC, Marimuthu T, C K, Devadoss P, Kumar SM. Prevalence and measurement of anterior loop of the mandibular canal using CBCT: A cross sectional study. Clin Implant Dent Relat Res. 2018 Aug;20(4):531-534. Pubmed PMID: 29624863.

[55]. Ramesh A, Varghese S, Jayakumar ND, Malaiappan S. Comparative estimation of sulfiredoxin levels between chronic periodontitis and healthy patients - A case-control study. J Periodontol. 2018 Oct;89(10):1241-1248. Pubmed PMID: 30044495.

[56]. Ramadurai N, Gurunathan D, Samuel AV, Subramanian E, Rodrigues SJL. Effectiveness of $2 \%$ Articaine as an anesthetic agent in children: randomized controlled trial. Clin Oral Investig. 2019 Sep;23(9):3543-3550. Pubmed PMID: 30552590

[57]. Sridharan G, Ramani P, Patankar S, Vijayaraghavan R. Evaluation of salivary metabolomics in oral leukoplakia and oral squamous cell carcinoma. J Oral Pathol Med. 2019 Apr;48(4):299-306. Pubmed PMID: 30714209.

[58]. Ezhilarasan D, Apoorva VS, Ashok Vardhan N. Syzygium cumini extract induced reactive oxygen species-mediated apoptosis in human oral squamous carcinoma cells. J Oral Pathol Med. 2019 Feb;48(2):115-121. Pubmed PMID: 30451321 .

[59]. Mathew MG, Samuel SR, Soni AJ, Roopa KB. Evaluation of adhesion of Streptococcus mutans, plaque accumulation on zirconia and stainless steel crowns, and surrounding gingival inflammation in primary molars: randomized controlled trial. Clin Oral Investig. 2020 Sep;24(9):3275-3280. Pubmed PMID: 31955271.

[60]. Samuel SR. Can 5-year-olds sensibly self-report the impact of developmental enamel defects on their quality of life? Int J Paediatr Dent. 2021 Mar;31(2):285-286. Pubmed PMID: 32416620.

[61]. R H, Ramani P, Ramanathan A, R JM, S G, Ramasubramanian A, et al. CYP2 C9 polymorphism among patients with oral squamous cell carcinoma and its role in altering the metabolism of benzo[a]pyrene. Oral Surg Oral Med Oral Pathol Oral Radiol. 2020 Sep;130(3):306-312. Pubmed PMID: 32773350 .

[62]. Chandrasekar R, Chandrasekhar S, Sundari KKS, Ravi P. Development and validation of a formula for objective assessment of cervical vertebral bone age. Prog Orthod. 2020 Oct 12;21(1):38. Pubmed PMID: 33043408.

[63]. Vijayashree Priyadharsini J, Smiline Girija AS, Paramasivam A. In silico analysis of virulence genes in an emerging dental pathogen A. baumannii and related species. Arch Oral Biol. 2018 Oct;94:93-98. Pubmed PMID: 30015217. 